\title{
Adenosine and Bone Metabolism
}

\author{
Aránzazu Mediero ${ }^{1}$ and Bruce N. Cronstein ${ }^{1,2}$ \\ ${ }^{1}$ Department of Medicine, Division of Translational Medicine, NYU School of Medicine, 550 First \\ Avenue, MSB251, New York, NY 10016, USA. \\ ${ }^{2}$ Department of Medicine, Division of Rheumatology, NYU School of Medicine, 550 First Avenue, \\ MSB251, New York, NY 10016, USA.
}

\begin{abstract}
Bone is a dynamic organ that undergoes continuous remodeling whilst maintaining a balance between bone formation and resorption. Osteoblasts, which synthesize and mineralize new bone, and osteoclasts, the cells that resorb bone, act in concert to maintain bone homeostasis. In recent years, there has been increasing appreciation of purinergic regulation of bone metabolism. Adenosine, released locally, mediates its physiologic and pharmacologic actions via interactions with G-protein coupled receptors and recent work has indicated that these receptors are involved in the regulation of osteoclast differentiation and function, as well as osteoblast differentiation and bone formation. Moreover, adenosine receptors also regulate chondrocyte and cartilage homeostasis. These recent findings underscore the potential therapeutic importance of adenosine receptors in regulating bone physiology and pathology.
\end{abstract}

\section{Keywords}

Adenosine; adenosine receptors; bone resorption; bone formation; chondrocytes

\section{Purinergic receptors}

Extracellular purines (adenosine, ATP and ADP) and pyrimidines (UDP and UTP) comprise a family of molecules that exert a variety of important physiological functions via the activation of cell-surface receptors termed purine receptors. Although the physiologic effects of adenosine and ATP have been recognized for over 80 years [1] purinergic receptors were first described in 1976 [2] and two subfamilies were identified; P1 or adenosine receptors and P2 or nucleotide receptors (Box 1). In this review we will primarily discuss the role of adenosine receptors in regulating bone metabolism.

\footnotetext{
(C) 2013 Elsevier Ltd. All rights reserved.

Corresponding author: Cronstein, B.N. Bruce.Cronstein @ nyumc.org.

Publisher's Disclaimer: This is a PDF file of an unedited manuscript that has been accepted for publication. As a service to our customers we are providing this early version of the manuscript. The manuscript will undergo copyediting, typesetting, and review of the resulting proof before it is published in its final citable form. Please note that during the production process errors may be discovered which could affect the content, and all legal disclaimers that apply to the journal pertain.

Conflicts of interest

$\mathrm{AM}$ holds patent adenosine $\mathrm{A} 2 \mathrm{~A}$ agonists to prevent prosthesis loosening (pending). BNC holds patents numbers 5,932,558; $6,020,321 ; 6,555,545 ; 7,795,427$; adenosine $\mathrm{A}_{1} \mathrm{R}$ and $\mathrm{A}_{2 \mathrm{~B}} \mathrm{R}$ antagonists to treat fatty liver (pending); adenosine $\mathrm{A}_{2} \mathrm{~A}$ R agonists to prevent prosthesis loosening (pending). BNC. is a consultant for Bristol-Myers Squibb, Novartis, CanFite Biopharmaceuticals, Cypress Laboratories, Regeneron (Westat, DSMB), Endocyte, Protalex, Allos, Inc., Savient, Gismo Therapeutics, Antares Pharmaceutical, Medivector, King Pharmaceutical, Celizome, Tap Pharmaceuticals, Prometheus Laboratories, Sepracor, Amgen, Combinatorx, Kyowa Hakka, Hoffman-LaRoche and Avidimer Therapeutics. BNC. has stocks in CanFite Biopharmaceuticlas.
} 


\section{P1 or adenosine receptors}

Adenosine is generated both intracellularly and extracellularly from the hydrolysis of adenine nucleotides (Figure 1), and acts locally to exert its extracellular physiologic and pharmacologic effects via activation of specific cell surface $G$ protein coupled receptors $\left(A_{1}\right.$, $A_{2 A}, A_{2 B}$ and $A_{3}$ ), proteins with unique pharmacological profile, tissue distribution and effector coupling [3]. As extracellular adenosine levels differ among tissues and in response to varying degrees of stress, the basal stimulation of each receptor by endogenous agonist varies [4]. Human adenosine receptors share 39-61\% sequence homology among them and 11-8\% homology with $\mathrm{P} 2 \mathrm{Y}$ receptors, in the transmembrane domains (TMI-TMVII) [5]. Classically, adenosine receptors have been divided on the basis of their ability to inhibit $\left(\mathrm{A}_{1}\right.$ and $\mathrm{A}_{3}$ receptor) or stimulate $\left(\mathrm{A}_{2 \mathrm{~A}}\right.$ and $\mathrm{A}_{2 \mathrm{~B}}$ receptors) adenylyl cyclase activity [6-8]. The increase in cAMP levels following activation of $\mathrm{A}_{2 \mathrm{~A}} \mathrm{R}$ and $\mathrm{A}_{2 \mathrm{~B}} \mathrm{R}$, or the inhibition of cAMP generation by $A_{1} R$, leads to activation of other signaling systems such as activation of several types of $\mathrm{K}^{+}$or $\mathrm{Ca}^{2+}$-channels, of phospholipase $\mathrm{C} \beta$ and MAPK $[3,4,9]$. In some cell types like $\mathrm{DDT}_{1} \mathrm{MF}-2$, HEK93 and $\mathrm{CHO}$ cells, adenosine receptors activate mitogenactivated protein kinases (MAPKs), serine/threonine-specific kinases which further mediate downstream signaling events [8]. Interestingly, adenosine $A_{1}$ and $A_{2}$ receptors $\left(A_{1} R\right.$ and $A_{2} R$ ) have opposing functional effects [10]. For example, during inflammation, $A_{1} R$ activation promotes multinucleated giant cell formation from peripheral blood monocytes, whereas $A_{2 A} R$ activation inhibits this phenomenon [11]. A variety of selective adenosine receptor agonists and antagonists have been identified, based on structural similarities to agonists such as adenosine, or antagonists such as xanthines or caffeine and theophylline [4] (Table 1).

\section{Bone homeostasis}

Bones are rigid tissues that constitute the vertebrate endoskeleton that provides structure, support and protection, and facilitates movement. Bone also produces red and white blood cells, has a metabolic function with the storage of minerals, growth factors and fat, and acts as and endocrine organ [19]. Several cell types comprise bone such as osteoblasts and osteoclasts.

\section{Osteoblasts}

Osteoblasts are mononuclear cells derived from pluripotent mesenchymal stem cells that synthesize bone proteins, including sialoprotein and osteocalcin, and mineralize bone during bone formation and bone remodeling [20]. During the proliferation phase from precursor to mature osteoblast, these cells synthesize and secrete collagen type I [20,21], which represents the majority (95\%) of organic matrix proteins in bone [22] Transcription factors responsible for the development of the osteoblast cell lineage including runt-related gene family such as core binding factor a 1 (Cbfa1) and Runx2, as well as c-fos and $c$-myc. Osteoblast differentiation and growth is controlled by local and systemic factors such as fibroblast growth factor (FGF), insulin-like growth factor (IGF), bone morphogenic proteins (BMPs) and wnt/ßcatenin [20].

\section{Osteoclasts}

Osteoclasts are the cells responsible for bone resorption. They are large, multinucleated cells derived from hematopoietic stem cells [23, 24], and are characterized by high expression of tartrate resistant acid phosphatase (TRAP) and cathepsin K. Osteoclasts are formed as a result of the stimulation by macrophage colony stimulating factor (M-CSF) and a complex network of regulatory factors that includes systemic hormones, locally produced cytokines and cell-cell and cell-matrix interactions [25, 26]. Receptor activator of nuclear factor 
kappa-B ligand (RANKL) has been identified as the critical extracellular regulator of osteoclast differentiation and activation [27-31]. Binding of RANKL to its receptor, RANK, on the surface of osteoclast precursors, stimulates the activation of several intracellular pathways including nuclear factor-kappaB (NF- $\kappa \mathrm{B}), \mathrm{c}-\mathrm{Fos}, \mathrm{PLC} \gamma$, and nuclear factor of activated T cells c1 (NFATc1). Osteoblasts tightly control osteoclast differentiation by expressing RANKL on their surface and secreting this osteoclast stimulus. Further control is mediated by osteoblast-mediated secretion of osteoprotegerin, a decoy receptor for RANKL $[32,33]$.

\section{Adenosine and Bone Metabolism}

Within the field of purinergic signaling, the regulation of bone metabolism by extracellular nucleotides started as early as 1989 [34] and has been reviewed recently [35, 36]. However, little was known about the role of adenosine in controlling bone metabolism. Although adenine nucleotides are present at high concentration in the cell, their half-life is short and they are subsequently degraded [37]. However, under pathological conditions, such as hypoxia, stress or inflammation, adenosine concentration increases [4]. Indeed, adenosine and its receptors are involved in the (patho)physiologic regulation of different pathways in various tissues and organs (e.g. vasodilation airway tone) and adenosine receptor are targets of various drugs such as dipyridamole and the disease-modifying anti-rheumatic drug methotrexate. In addition, recent findings highlighting the significance of adenosine and its receptors in bone metabolism has opened new areas for exploration in understanding endogenous control of bone metabolism.

\section{Role of adenosine and its receptors in osteoclast metabolism}

Under physiological conditions, intracellular adenosine concentrations are relatively low $(<1 \mu \mathrm{M})$. Extracellular adenosine levels are regulated by both production and catabolism. Adenosine is produced extracellularly from adenine nucleotides by the action of a series of ectonucleotidases. The half-life of adenosine is short and a result of both facilitated cellular uptake, mediated by the transmembrane glycoprotein and member of the equilibrative nucleoside transporter family equilibrative nucleoside transporter 1 (ent1), and adenosine kinase-mediated rephosphorylation of adenosine, intracellularly [38]. In addition, adenosine is deaminated by adenosine deaminase to inosine. The recycling of adenosine and ATP is perturbed during conditions of metabolic stress, high cellular activity or cell death. These perturbations produce an increase in phosphatase activities, that together with an increase in diffusion, secondary transport of nucleotides and activation of ecto- $5^{\prime}$-nucleotidases (CD73), result in an extracellular accumulation of adenosine and activation of adenosine receptors.

$\mathbf{A}_{\mathbf{1}} \mathbf{R}$-In 1987, Fredholm et al demonstrated the presence of functional $\mathrm{A}_{2}$ and $\mathrm{P}_{2}$ receptors in mouse calvaria, but could not show presence of $A_{1}$-receptors [39]. Subsequent studies demonstrated the presence of all four adenosine receptors in murine bone marrow cell osteoclast precursors, splenocytes and in the monocytic cell line RAW264.7, and further demonstrated that these receptors were up-regulated during osteoclast differentiation [40]. Since this discovery, studies in bone cells (Figure 2), have revealed that $A_{1} R$ is critical for osteoclast differentiation and function and that $A_{1} R$ blockade (with the specific synthetic inhibitor DPCPX) or deletion ( $\mathrm{A}_{1}$ knockout mice) increases bone density and prevents ovariectomy-induced bone loss, in mice [40,41]. This increased in bone density due to the blockade of $\mathrm{A}_{1} \mathrm{R}$ results from suppression of RANKL-induced expression of the transcription factors NFATc1 and c-fos, the inhibition of RANKL-induced NFrB activation. There is also a disruption in the RANKL-induced formation of a complex between TNF receptor associated factor 6 and the TAK1 kinase (TRAF6-TAK1), which is required during 
osteoclastogenesis [42]. Moreover, He et al demonstrated that the $\mathrm{A}_{1} \mathrm{R}$ is constitutively activated. Stimulation of the receptor by CPA does not directly affect osteoclastogenesis whereas the presence of the $\mathrm{A}_{1} \mathrm{R}$ antagonists DPCPX or rolofylline, inhibit osteoclast formation [42]. These observations are consistent with the hypothesis that the $A_{1} R$ antagonists act as inverse agonists, agents that diminish activity of a constitutively active receptor [43]. In contrast to these works, Pellegatti et al [44] reported modest expression of $\mathrm{A}_{1} \mathrm{R}$ in both quiescent or MCSF/RANKL activated human monocytes, suggesting that $\mathrm{A}_{1} \mathrm{R}$ does not play a role in osteoclastogenesis, while proposing that experimental disparities between studies may be due to species differences.

$\mathbf{A}_{2 A} \mathbf{R}$ - In contrast to $\mathrm{A}_{1} \mathrm{R}, \mathrm{A}_{2 \mathrm{~A}} \mathrm{R}$ activation opposes osteoclastogenesis. The $\mathrm{A}_{2 \mathrm{~A}} \mathrm{R}$ agonist, CGS21680, inhibits osteoclast differentiation and function and increases the percentage of immature osteoclast precursors, in part by decreasing IL-1 $\beta$ and TNFa secretion [45]. Either antagonism or deletion of $\mathrm{A}_{2 \mathrm{~A}} \mathrm{R}$ abrogates stimulation of osteoclastogenesis in vitro and both dual-energy X-ray absorptiometry (DEXA) scanning and X-ray microtomography (microCT) examination demonstrated that mice deficient in $\mathrm{A}_{2 \mathrm{~A}} \mathrm{R}$ have a marked diminution of bone density, consistent with a marked increase in the number, and apparent function of, TRAP-positive osteoclasts [45]. Mediero, et al have reported that bone marrow-derived osteoclasts from normal and multiple myeloma patients are similarly affected by $\mathrm{A}_{2 \mathrm{~A}} \mathrm{R}$ [46], in contrast to the findings of Pellegatti and colleagues [44] who observed that $\mathrm{A}_{2 \mathrm{~A}} \mathrm{R}$ stimulation increases human osteoclast differentiation [44, 47]. The discrepancies among these groups may be explained by the different sources of osteoclast presurors used in the assays. Mediero et al performed their studies using bone marrow-derived osteoclast precursors, whereas the Pellegatti and Gartland groups used stimulated peripheral blood monocytes. This difference may also account for the variation in adenosine receptor expression and function resulting from blockade of the $\mathrm{P} 2 \mathrm{X}_{7}$ receptor.

The inhibitory effects of $\mathrm{A}_{2 \mathrm{~A}} \mathrm{R}$ on osteoclast differentiation may have therapeutic importance as well; as adenosine mediates the anti-inflammatory effects of the drug methotrexate [48] we speculate that the capacity of methotrexate to inhibit bone erosion in patients with rheumatoid arthritis (RA) may be mediated by adenosine stimulation of $\mathrm{A}_{2 \mathrm{~A}} \mathrm{R}$. Consistent with this hypothesis is the finding by Mazzon et al that adenosine, acting via the $\mathrm{A}_{2 \mathrm{~A}}$ receptor, reduces bone resorption in a collagen-induced mouse model of RA [49].

Mediero et al have reported another important in vivo role for $\mathrm{A}_{2 \mathrm{~A}} \mathrm{R}$ activation on osteoclasts. Hip and knee replacements are common, successful surgical interventions that are employed in an increasing number of individuals suffering from painful and degenerative diseases of the joints. In a model of wear particle-induced osteolysis, $\mathrm{A}_{2 \mathrm{~A}} \mathrm{R}$ agonists were shown to reduce bone pitting and loss, by diminishing inflammation and decreasing the number of osteoclasts [46].

$\mathbf{A}_{\mathbf{2}} \mathbf{R}$ and $\mathbf{A}_{\mathbf{3}} \mathbf{R}$ - Little is known about the involvement of the other two adenosine receptors, $A_{2 B} R$ and $A_{3} R$, in osteoclast differentiation and bone resorption. In 1999, Xaus et al found that adenosine produced during inflammation was able to inhibit differentiation of murine bone marrow-derived macrophages in the presence of M-CSF, via the activation of the adenosine $\mathrm{A}_{2 \mathrm{~B}}$ receptor $\left(\mathrm{A}_{2 \mathrm{~B}} \mathrm{R}\right)$ and subsequent production of cAMP [50]. These investigators [42] observed that the $\mathrm{A}_{2 \mathrm{~B}} \mathrm{R}$ agonist BAY606583 inhibits RANKL-induced osteoclast formation and expression of osteoclast markers, in murine cells. In contrast, Teramachi et al reported that adenosine abolished methotrexate-induced osteoclast inhibition by activation of $\mathrm{A}_{2 \mathrm{~B}} \mathrm{R}$ [51], although the effect on osteoclast differentiation was more likely due to an action of adenosine on osteoblast production of RANKL and osteoprotegerin following methotrexate treatment. An additional report documented the expression of $\mathrm{A}_{2 \mathrm{~B}} \mathrm{R}$ in human osteoclast precursors and differentiated [44]. However, the investigators did not observe any effect on osteoclast differentiation or function driven by $\mathrm{A}_{2 \mathrm{~B}} \mathrm{R}$ activation or 
inhibition. Rath-Wolfson et al reported that IB-MECA, a potent and selective $\mathrm{A}_{3} \mathrm{R}$ agonist, [52] ameliorates cartilage and bone destruction and decreases the number of osteoclasts, in a rat model of arthritis, although this effect is most likely secondary to diminished inflammation.

Collectively, these studies reveal a role for adenosine in osteoclast metabolism; the $A_{1} R$ is constitutively activated and required for appropriate osteoclast differentiation and function whereas the activation of the $\mathrm{A}_{2 \mathrm{~A}}$ receptor exerts the opposite effect that is inhibition of osteoclast function.

\section{Role of adenosine and its receptors in osteoblast metabolism}

In 1996 Shimeri et al reported that adenosine acts as a mitogen for the osteoblast cell line MC3T3-E1 [53], although the authors believed that since ATP had a stronger effect than adenosine, it was unlikely that this mitogenic action was caused by ectoenzyme-mediated ATP metabolites. It was later reported that methotrexate suppresses bone formation by inhibiting the differentiation of early osteoblastic cells in both MC3T3-E1 cells and rat bone marrow stromal cells [54], and that adenosine mediates many of the actions of methotrexate [55]. A subsequent study demonstrated the presence of extracellular adenosine and all four adenosine receptors in human osteoprogenitor cells [37]. Moreover, this work showed that there was a change in the secretion of two key modulators of osteoclastogenesis, osteoprotegerin, and the pro-inflammatory cytokine IL-6. Using the same cell line Russell et al reported in 2007 [56] that $A_{2 A} R$ regulates IL-6 secretion induced by lipopolysaccharide (LPS) treatment, suggesting a role for adenosine receptors in the control of inflammation, and potentially osteoclastogenesis and bone resorption. More recently, Costa et al investigated the presence and function of four adenosine receptors during differentiation of human bone marrow stromal cells from postmenopausal women in vitro; cells were cultured in osteogenic conditions where the adenosine that is generated from extracellular ATP catabolism exerts a powerful proliferative action [57]. The authors showed that selective agonists for $A_{1} R, A_{2 A} R, A_{2 B} R$ and $A_{3} R$ increase human primary osteoblast proliferation, and that selective receptor antagonists block proliferation (Figure 3).

However, additional controversies exist in relation to the presence of functional adenosine receptors and adenosine effects in primary calvarial cultures that need more exploration. Fredholm et al $[39,58]$ have reported the presence of $\mathrm{A}_{2}$ receptors in osteoblast-like cells from neonatal mouse calvaria bones, whereas Jones and colleagues found no effect of adenosine on rat calvarial osteoblast cultures [58].

$\mathbf{A}_{\mathbf{1}} \mathbf{R}$-Little is known about the role of the $A_{1} R$ in osteoblast differentiation and function. As mention above, Fredholm et al demonstrated the presence of $A_{2}$ and $P_{2}$ receptors in osteoblast-like cells, but not the presence of $A_{1} R$ [39]. Two recent papers $[59,60]$ show that $A_{1} R$ is present in mouse mesenchymal stem cells and in $7 F 2$ osteoblasts, although the stimulation of this receptor decreases alkaline phosphatase activity, a finding consistent with stimulation of adipocyte differentiation, as lipoprotein lipase activity is increased while alkaline phosphatase is decreased. Moreover, no morphologic changes in osteoblasts were observed in $\mathrm{A}_{1} \mathrm{R}$-knockout mice, and bone-labeling studies revealed no change in the bone formation rates [41].

$\mathbf{A}_{\mathbf{2 A}} \mathbf{R}$-As noted above, Russell at al [56] reported that adenosine inhibition of LPSinduced IL-6 secretion in an in vitro inflammatory model in the osteoblastic cell line MG-63 was due to the action of $\mathrm{A}_{2 \mathrm{~A}} \mathrm{R}$ on the cAMP/Protein Kinase A (PKA) pathway. Moreover, Katebi et al showed that adenosine, acting via $\mathrm{A}_{2 \mathrm{~A}} \mathrm{R}$, plays a critical role in promoting the proliferation of mouse bone marrow-derived mesenchymal stem cells [61]. Finally, it was 
recently reported that $\mathrm{A}_{2 \mathrm{~A}} \mathrm{R}$ is up-regulated in later osteoblast differentiation stages, and increases alkaline phosphatase activity [60]. Moreover, adenosine modulates cell viability in the osteoblast MC3T3 cell line in response to oxidative damage by hydrogen peroxide $\left(\mathrm{H}_{2} \mathrm{O}_{2}\right)$ [62]. Both $\mathrm{A}_{1} \mathrm{R}$ and $\mathrm{A}_{2 \mathrm{~A}} \mathrm{R}$ activation significantly increases cell viability and also protect against oxidative damage. When $A_{1} R$ is blocked with the specific antagonist DPCPX, cell viability increases for up to $1 \mathrm{~h}$ after incubation, but the effect disappears when incubation is prolonged. In contrast, the $\mathrm{A}_{2 \mathrm{~A}} \mathrm{R}$ agonist CGS21680 increases cell number, when applied for $6 \mathrm{~h}$ at a low concentration, or at a high concentration and for a shorter period. Finally, the effects of $\mathrm{A}_{2 \mathrm{~A}} \mathrm{R}$ deletion on osteoblast function have not been reported.

$\mathbf{A}_{2 B} \mathbf{R}$-Strong evidence implicates $A_{2 B} R$ in osteoblast differentiation and function. There is a decrease in osteoblast differentiation, osteoblast-related transcription factor expression and mineralized nodules in mesenchymal cells from $\mathrm{A}_{2 \mathrm{~B}} \mathrm{R} \mathrm{KO}$ mice as compared to WT mice [63]. $A_{2 B} R$ is the predominant receptor in human osteoprogenitor cells [37], and Gharibi et al have also found that it is also the functionally predominant adenosine receptor in rat bone marrow-derived cells, and that its expression is transiently up-regulated at early stages of osteoblast differentiation. This transient overexpression of $\mathrm{A}_{2 \mathrm{~B}} \mathrm{R}$ induces the expression of the osteoblast-related genes Runx 2 as well as expression and activity of alkaline phosphatase (ALP), a marker for osteoblast differentiation [60] Costa et al recently reported that blockade of $\mathrm{A}_{2 \mathrm{~B}} \mathrm{R}$ with the specific antagonist PSB603 abrogated the increased osteoblast differentiation of human primary mesenchymal cells that were stimulated with the non-selective adenosine receptor agonist (NECA) [57]. This is in contrast to a prior report showing that this same agent does not affect proliferation in a human osteoprogenitor cell line, even though the concentrations used were similar in both studies. It was recently reported that $\mathrm{A}_{2 \mathrm{~B}} \mathrm{R}$ is important in osteoblast differentiation [64]. Indeed, when MC3T3-E1 cells overexpress the enzyme cluster of differentiation 73 (CD73) that converts AMP to adenosine, there is increased expression of osteocalcin and bone sialoprotein that is abrogated when $A_{2 B} R$, but not the $A_{2 A} R$, is blocked. These results are consistent with the hypothesis that $C D 73$-generated adenosine activates $A_{2 B} R$ signaling to regulate osteoblast differentiation.. Subsequently Carroll et al [63] reported that osteoblast differentiation is mediated by a cAMP-related mechanism since activation of $\mathrm{A}_{2 \mathrm{~B}} \mathrm{R}$ or addition of the cAMP analog 8-bromoadenosine- $3^{\prime}, 5^{\prime}$-cyclic monophosphate (8-br-cAMP) enhances osteoblast differentiation in a parallel fashion. Moreover, when studied in vivo by microcomputed tomography analysis $(\mu \mathrm{CT})$, long bones from adult mice lacking $\mathrm{A}_{2 \mathrm{~B}} \mathrm{R}$ had lower bone density than wild type animals, and suffered delayed fracture healing, with lower expression of osteoblast differentiation genes (Runx2 and Osterix). Finally, Gharibi et al [59] reported that although both $A_{1} R$ and $A_{2 B} R$ are expressed in osteoblast precursors, $A_{1} R$ induces adipocyte differentiation whereas $A_{2 B} R$ inhibits adipogenesis and stimulates osteoblast differentiation, suggesting that targeting these receptors may be useful in treatment strategies for diseases where an imbalance between osteoblasts and adipocytes exists. Thus, these studies are consistent with the hypothesis that $\mathrm{A}_{2 \mathrm{~B}} \mathrm{R}$ is a key modulator of skeletal repair and absence or blockade of $\mathrm{A}_{2 \mathrm{~B}} \mathrm{R}$ leads to delayed progression of bone development during fracture.

$\mathbf{A}_{3} \mathbf{R}$-Finally, with respect to $A_{3} R$, little is known. This receptor is expressed on osteoblasts and osteoblast precursors [37] and a selective agonist for $A_{3} R$ increases human primary osteoblast proliferation, which is abrogated in the presence of the antagonist [57].

In summary, all four adenosine receptors are expressed by bone marrow stromal cells and differentiated osteoblasts. Although the $\mathrm{A}_{2 \mathrm{~B}} \mathrm{R}$ is dominant and is up-regulated during osteoblast differentiation, new evidence suggests the involvement of $A_{1} R, A_{2 A} R$ and $A_{3} R$ in osteoblast differentiation. 


\section{Role of adenosine and its receptors in cartilage metabolism}

When studying the role of purinergic signaling in cartilage metabolism, most of the attention has been on P2 receptors. Extracellular nucleotides have been shown to have diverse effects on chondrocyte function. Nonetheless, adenosine and its receptors have a role in regulating cartilage and chondrocyte function (Figure 4).

Adenosine metabolism-Children that suffer from a deficiency in the enzyme adenosine deaminase, a genetic mutation that leads to elevated adenosine levels in extracellular fluids, also suffer from severe combined immunodeficiency. These children exhibit marked changes in the chondro-osseous tissue of vertebrae and costochondral junction, have increased necrotic chondrocytes, and large amounts of cellular debris. All of these changes are ameliorated when patients received bone marrow transplants or multiple partial exchange transfusions [65]. This work suggested that adenosine might regulate cartilage biology. Along these lines, Tesch et al reported that equine articular chondrocytes [66] release adenosine in response to pro-inflammatory stimuli (LPS), and alteration of adenosine metabolism by an adenosine kinase inhibitor $\left(5^{\prime}\right.$-iodotubercidin, ITU) or the adenosine deaminase inhibitor erythro-9-(2-hydroxy-3-nonyl)adenine hydrochloride (EHNA) increases accumulation of extracellular adenosine. This finding suggests that autocrine release of adenosine from chondrocytes may play a role in the cellular response to tissue damage in arthritic conditions.

$\mathbf{A}_{\mathbf{2 A}} \mathbf{R}$-Activation of $\mathrm{A}_{2 \mathrm{~A}} \mathrm{R}$ increases intracellular cAMP accumulation together with suppression of nitric oxide (NO) and these effects are enhanced by the adenosine deaminase inhibitor EHNA or by potentiating the cAMP response with the selective phosphodiesterase inhibitor rolipram [67]. Similarly, Petrov et al reported that inhibition of adenosine kinase by ITU attenuates IL-1 $\beta$-induced prostaglandin E2 (PGE2) release, and LPS-induced NO production in articular cartilage metabolism in metacarpophalangeal joints of young adult horses [68]. Moreover, Tesch et al revealed that endogenous adenosine levels regulate cartilage matrix homeostasis even in the absence of inflammation, in part due to the activation of cell surface adenosine receptors. Exposure to adenosine deaminase induces an increase in glycosaminoglycan release and production of total matrix metalloproteinase-3 (MMP-3), MMP-13, PGE2, and NO, while blockade of $\mathrm{A}_{2 \mathrm{~A}} \mathrm{R}$ inhibits this effect [69].

Given that adenosine receptors regulate chondrocyte biology and cartilage matrix it was not surprising that adenosine and its receptors were reported to play a role in osteoarthritis in a murine model [70]. Furthermore, studies using polydeoxyribonucleotides (PDRN) a mixture of deoxyribonucleotide polymers with chain lengths ranging from 50 to 2,000 base pairs that have been shown to activate $A_{2 A} R$, showed a significant amelioration in the clinical signs of osteoarthritis, reduction in cartilage expression and circulating levels of TNFa, and IL-6, and enhanced IL-10 expression. PDRN also reduced cytokine production from stimulated human chondrocytes [71]. In addition, all four adenosine receptors are expressed and similarly distributed in bovine chondrocytes and fibroblast-like synoviocytes. The $\mathrm{A}_{2 \mathrm{~A}} \mathrm{R}$ and $\mathrm{A}_{3} \mathrm{R}$ are up-regulated with a subsequent increase in cAMP and cellular proliferation resulting in amelioration of joint disease [72]. Recent studies have confirmed and expanded the role of $\mathrm{A}_{2 \mathrm{~A}} \mathrm{R}$ in articular chondrocytes. Treatment of murine chondrocytes with the hyaluronan (HA)-blocking peptide Pep-1 and/or the specific $\mathrm{A}_{2 \mathrm{~A}} \mathrm{R}$ agonist, CGS21680, significantly reduced all the inflammatory molecules up-regulated by IL-1 $\beta$ [73]. Moreover, treatment of primary murine chondrocyte cultures with the selective $\mathrm{A}_{2 \mathrm{~A}} \mathrm{R}$ agonist CV-1808 blocked up-regulation of the cell-surface glycoprotein CD44 and Toll-like receptor 4 (TLR4), and significantly reduced NFkB activation and pro-inflammatory cytokine production [74]. The same work elucidated the roles of exchange protein activated by cAMP (EPAC) and PKA, showing a predominant EPAC involvement in mediation of the anti- 
inflammatory activity of $\mathrm{A}_{2 \mathrm{~A}} \mathrm{R}$. However, the same group has also reported that adenosine treatment increases intracellular cAMP and PKA activity and suggested, that hyaluronan (HA) fragments produced by degradation of native highly polymerized HA during inflammation, are partially responsible for the up-regulation of pro-inflammatory cytokines in chondrocytes, which is inhibited by adenosine receptor-stimulated activation of PKA [75].

It is clear that in response to inflammation, adenosine is released into the joint space and the activation of $\mathrm{A}_{2 \mathrm{~A}} \mathrm{R}$ ameliorates cartilage destruction, but more studies are needed for a better understanding of the role of adenosine in cartilage biology.

\section{Concluding remarks}

All four adenosine receptors are expressed by bone marrow cells, osteoclasts and osteoblasts, consistent with the hypothesis that adenosine and its receptors play a role in bone and cartilage homeostasis. The $\mathrm{A}_{1} \mathrm{R}$ is critical for osteoclast differentiation and function, indeed agents that antagonize this receptor act as inverse agonists to inhibit osteoclast differentiation. In contrast, activation of the $\mathrm{A}_{2 \mathrm{~A}} \mathrm{R}$ inhibits osteoclastogenesis. In the case of osteoblast differentiation, it has been reported that $A_{2 A} R$ plays a critical role in promoting the proliferation of mouse bone marrow-derived mesenchymal stem cells, but the $\mathrm{A}_{2 \mathrm{~B}} \mathrm{R}$ is the functionally dominant adenosine receptor involved in osteoblast differentiation. Moreover, adenosine receptors regulate chondrocyte biology and cartilage matrix as the $\mathrm{A}_{2 \mathrm{~A}} \mathrm{R}$ and $\mathrm{A}_{3} \mathrm{R}$ are up-regulated and their activation ameliorates joint disease. When studied in vivo all four adenosine receptors regulate bone formation in a manner consistent with their in vitro effects: $\mathrm{A}_{1} \mathrm{R}$ blockade or deletion increases bone density; $\mathrm{A}_{2 \mathrm{~A}} \mathrm{R}$ activation inhibits inflammatory osteolysis whereas $\mathrm{A}_{2 \mathrm{~A}} \mathrm{R}$ blockade leads to excessive bone resorption and osteopenia; $\mathrm{A}_{2 \mathrm{~B}} \mathrm{R}$ deletion or blockade diminishes bone density. Future and ongoing investigations will help elucidate the intracellular pathways involved in adenosine receptor signaling that regulate bone metabolism. It will also be of interest to determine how well actions in human cells parallel those observed in mice and other species and how well these actions translate to new therapies for bone disease.

\section{Acknowledgments}

This work was supported by grants from the National Institutes of Health (AR56672, AR54897, AR046121), the NYU-HHC Clinical and Translational Science Institute (UL1TR000038) and grants from Takeda and Gilead Pharmaceuticals.

\section{Glossary box}

\author{
Adenosine \\ Adenosine \\ receptors \\ Bone formation \\ (osteogenesis)
}

Bone resorption purine nucleoside form of a molecule of adenine attached to a ribose sugar moiety via a $\beta-\mathrm{N}_{9}$-glycosidic bond.

class of purinergic receptors, $\mathrm{G}$ protein-coupled receptors with adenosine as endogenous ligand.

begins during prenatal development and persists throughout adulthood. There are two ways in which osteogenesis occurs: intramembranous ossification and endochondral ossification. Osteoblasts, used mainly in intramembranous ossification, meanwhile osteoclasts, used in are involved in remodeling of bone after formation.

is the process by which osteoclasts break down bone. 
M-CSF

Osteoarthritis

Osteoblasts

Osteoclast

Osteoprotegerin (OPG)

RANKL

\section{Rheumatoid} arthritis
Macrophage colony-stimulating factor, a secreted cytokine which influences hematopoietic stem cells to differentiate into macrophages or other related cell types.

a group of mechanical abnormalities involving degradation of joints, including articular cartilage and subchondral bone. When bone surfaces become unprotected by cartilage, bone can be damage, resulting in a decreased movement secondary to pain, regional muscles atrophy and lax ligaments.

are mononuclear cells responsible for bone formation. They are specialized mesenchymal cells that express bone sialoprotein and osteocalcin. Osteoblasts produce a matrix of osteoid, which is composed mainly of Type I collagen.

large, multinucleated cells derived from hematopoietic stem cells responsible for resorbing bone by removing the mineralized matrix and breaking up the organic bone. Osteoclasts are formed by the fusion of cells of the monocyte-macrophage cell line and are characterized by high expression of tartrate resistant acid phosphatase (TRAP) and cathepsin K.

also known as osteoclastogenesis inhibitory factor (OCIF), or tumor necrosis factor receptor superfamily member 11B (TNFRSF11B), is a decoy protein that bind to RANK and inhibits osteoclast differentiation.

Receptor activator of nuclear factor kappa-B ligand, also known as tumor necrosis factor ligand superfamily member 11 (TNFSF11), TNF-related activation-induced cytokine (TRANCE), osteoprotegerin ligand (OPGL), and osteoclast differentiation factor (ODF), is a critical for adequate bone metabolism. It is secreted by the osteoblasts and serves to activate osteoclasts by binding to its specific surface-bound membrane receptor RANK ( receptor activator of nuclear factor kappa-B).

a chronic, systemic autoimmune inflammatory disorder that affect principally synovial joints. The pathogenesis of Rheumatoid Arthritis involves inflammation of the synovium with destruction of the articular cartilage and bone. Extra-articular manifestations of Rheumatoid Arthritis include inflammatory lesions of the lungs, pericardium, pleura and sclera.

\section{REFERENCES}

1. Drury AN, Szent-Gyorgi A. The physiological activity of adenine compounds with special reference to their action upon the mammalian heart. Journal of Physiology. 1929; 68:213-237. [PubMed: 16994064]

2. Burnstock G. Purinergic receptors. J Theor Biol. 1976; 62:491-503. [PubMed: 994531]

3. Fredholm BB, et al. International Union of Basic and Clinical Pharmacology. LXXXI. Nomenclature and Classification of Adenosine Receptors--An Update. Pharmacol Rev. 2011; 63:134. [PubMed: 21303899]

4. Jacobson KA, Gao ZG. Adenosine receptors as therapeutic targets. Nat Rev Drug Discov. 2006; 5:247-264. [PubMed: 16518376] 
5. Burnstock G. Purine and pyrimidine receptors. Cell Mol Life Sci. 2007; 64:1471-1483. [PubMed: 17375261]

6. van Calker D, et al. Adenosine regulates via two different types of receptors, the accumulation of cyclic AMP in cultured brain cells. J Neurochem. 1979; 33:999-1005. [PubMed: 228008]

7. Londos C, et al. Subclasses of external adenosine receptors. Proceedings of the National Academy of Sciences of the United States of America. 1980; 77:2551-2554. [PubMed: 6248853]

8. Verzijl D, Ijzerman AP. Functional selectivity of adenosine receptor ligands. Purinergic Signal. 2011; 7:171-192. Epub 2011 May 2015. [PubMed: 21544511]

9. Fredholm BB, et al. Comparison of the potency of adenosine as an agonist at human adenosine receptors expressed in Chinese hamster ovary cells. Biochemical pharmacology. 2001; 61:443-448. [PubMed: 11226378]

10. Schulte G, Fredholm BB. Signalling from adenosine receptors to mitogen-activated protein kinases. Cell Signal. 2003; 15:813-827. [PubMed: 12834807]

11. Merrill JT, et al. Adenosine A1 receptor promotion of multinucleated giant cell formation by human monocytes: a mechanism for methotrexate-induced nodulosis in rheumatoid arthritis. Arthritis Rheum. 1997; 40:1308-1315. [PubMed: 9214432]

12. Burnstock G, Knight GE. Cellular distribution and functions of $P 2$ receptor subtypes in different systems. Int Rev Cytol. 2004; 240:31-304. [PubMed: 15548415]

13. Burnstock G, Kennedy C. Is there a basis for distinguishing two types of P2-purinoceptor? Gen Pharmacol. 1985; 16:433-440. [PubMed: 2996968]

14. Burnstock G, Williams M. P2 purinergic receptors: modulation of cell function and therapeutic potential. J Pharmacol Exp Ther. 2000; 295:862-869. [PubMed: 11082418]

15. Weisman GA, et al. Molecular determinants of P2Y2 nucleotide receptor function: implications for proliferative and inflammatory pathways in astrocytes. Mol Neurobiol. 2005; 31:169-183. [PubMed: 15953819]

16. North RA, Surprenant A. Pharmacology of cloned P2X receptors. Annu Rev Pharmacol Toxicol. 2000; 40:563-580. [PubMed: 10836147]

17. Boeynaems JM, et al. Overview of the P2 receptors. Semin Thromb Hemost. 2005; 31:139-149. [PubMed: 15852217]

18. Sellers LA, et al. Adenosine nucleotides acting at the human P2Y1 receptor stimulate mitogenactivated protein kinases and induce apoptosis. J Biol Chem. 2001; 276:16379-16390. Epub 12001 Jan 16325. [PubMed: 11278310]

19. Fukumoto S, Martin TJ. Bone as an endocrine organ. Trends Endocrinol Metab. 2009; 20:230-236. [PubMed: 19546009]

20. Neve A, et al. Osteoblast physiology in normal and pathological conditions. Cell Tissue Res. 2011; 343:289-302. [PubMed: 21120535]

21. Johansen JS, et al. Identification of proteins secreted by human osteoblastic cells in culture. J Bone Miner Res. 1992; 7:501-512. [PubMed: 1615759]

22. Bussard KM, et al. The bone microenvironment in metastasis; what is special about bone? Cancer Metastasis Rev. 2008; 27:41-55. [PubMed: 18071636]

23. Suda T, et al. Modulation of osteoclast differentiation and function by the new members of the tumor necrosis factor receptor and ligand families. Endocr Rev. 1999; 20:345-357. [PubMed: 10368775]

24. Manolagas SC. Birth and death of bone cells: basic regulatory mechanisms and implications for the pathogenesis and treatment of osteoporosis. Endocr Rev. 2000; 21:115-137. [PubMed: 10782361]

25. McHugh KP, et al. Role of cell-matrix interactions in osteoclast differentiation. Adv Exp Med Biol. 2007; 602:107-111. [PubMed: 17966395]

26. Takayanagi H. Osteoimmunology: shared mechanisms and crosstalk between the immune and bone systems. Nat Rev Immunol. 2007; 7:292-304. [PubMed: 17380158]

27. Yoshida H, et al. The murine mutation osteopetrosis is in the coding region of the macrophage colony stimulating factor gene. Nature. 1990; 345:442-444. [PubMed: 2188141] 
28. Yasuda H, et al. Osteoclast differentiation factor is a ligand for osteoprotegerin/osteoclastogenesisinhibitory factor and is identical to TRANCE/RANKL. Proceedings of the National Academy of Sciences of the United States of America. 1998; 95:3597-3602. [PubMed: 9520411]

29. Simonet WS, et al. Osteoprotegerin: a novel secreted protein involved in the regulation of bone density. Cell. 1997; 89:309-319. [PubMed: 9108485]

30. Dougall WC, et al. RANK is essential for osteoclast and lymph node development. Genes Dev. 1999; 13:2412-2424. [PubMed: 10500098]

31. Li J, et al. RANK is the intrinsic hematopoietic cell surface receptor that controls osteoclastogenesis and regulation of bone mass and calcium metabolism. Proceedings of the National Academy of Sciences of the United States of America. 2000; 97:1566-1571. [PubMed: 10677500]

32. Nelson CA, et al. RANKL Employs Distinct Binding Modes to Engage RANK and the Osteoprotegerin Decoy Receptor. Structure. 2012; 20:1971-1982. [PubMed: 23039992]

33. Dougall WC. Molecular pathways: osteoclast-dependent and osteoclast-independent roles of the RANKL/RANK/OPG pathway in tumorigenesis and metastasis. Clin Cancer Res. 2012; 18:326335. [PubMed: 22031096]

34. Kumagai H, et al. Neurotransmitter regulation of cytosolic calcium in osteoblast-like bone cells. Calcif Tissue Int. 1989; 45:251-254. [PubMed: 2553224]

35. Hoebertz A, et al. Regulation of bone resorption and formation by purines and pyrimidines. Trends Pharmacol Sci. 2003; 24:290-297. [PubMed: 12823955]

36. Orriss IR, et al. Purinergic signalling and bone remodelling. Curr Opin Pharmacol. 2010; 10:322330. [PubMed: 20189453]

37. Evans BA, et al. Human osteoblast precursors produce extracellular adenosine, which modulates their secretion of IL-6 and osteoprotegerin. J Bone Miner Res. 2006; 21:228-236. [PubMed: 16418778]

38. Fredholm BB. Adenosine receptors as drug targets. Exp Cell Res. 2010; 316:1284-1288. [PubMed: 20153317]

39. Lerner UH, et al. Characterization of adenosine receptors in bone. Studies on the effect of adenosine analogues on cyclic AMP formation and bone resorption in cultured mouse calvaria. Acta Physiol Scand. 1987; 131:287-296. [PubMed: 2823534]

40. Kara FM, et al. Adenosine A1 receptors (A1Rs) play a critical role in osteoclast formation and function. FASEB journal : official publication of the Federation of American Societies for Experimental Biology. 2010; 24:2325-2333. [PubMed: 20181934]

41. Kara FM, et al. Adenosine A(1) receptors regulate bone resorption in mice: adenosine A(1) receptor blockade or deletion increases bone density and prevents ovariectomy-induced bone loss in adenosine A(1) receptor-knockout mice. Arthritis Rheum. 2010; 62:534-541. [PubMed: 20112380]

42. He W, Cronstein BN. Adenosine A1 receptor regulates osteoclast formation by altering TRAF6/ TAK1 signaling. Purinergic Signal. 2012; 8:327-337. [PubMed: 22311477]

43. Shryock JC, et al. Inverse agonists and neutral antagonists of recombinant human A1 adenosine receptors stably expressed in Chinese hamster ovary cells. Mol Pharmacol. 1998; 53:886-893. [PubMed: 9584215]

44. Pellegatti $\mathrm{P}$, et al. $\mathrm{P} 2 \mathrm{X} 7$ receptor drives osteoclast fusion by increasing the extracellular adenosine concentration. FASEB journal : official publication of the Federation of American Societies for Experimental Biology. 2011; 25:1264-1274. [PubMed: 21233486]

45. Mediero A, et al. Adenosine A2A Receptor Ligation Inhibits Osteoclast Formation. Am J Pathol. In press.

46. Mediero A, et al. Adenosine A2A receptor activation prevents wear particle-induced osteolysis. Sci Transl Med. 2012; 4:135ra165.

47. Gartland A, et al. Blockade of the pore-forming P2X7 receptor inhibits formation of multinucleated human osteoclasts in vitro. Calcif Tissue Int. 2003; 73:361-369. [PubMed: 12874700] 
48. Cronstein BN, et al. The antiinflammatory mechanism of methotrexate. Increased adenosine release at inflamed sites diminishes leukocyte accumulation in an in vivo model of inflammation. $\mathrm{J}$ Clin Invest. 1993; 92:2675-2682. [PubMed: 8254024]

49. Mazzon E, et al. CGS 21680, an agonist of the adenosine (A2A) receptor, reduces progression of murine type II collagen-induced arthritis. J Rheumatol. 2011; 38:2119-2129. [PubMed: 21765105]

50. Xaus J, et al. Adenosine inhibits macrophage colony-stimulating factor-dependent proliferation of macrophages through the induction of p27kip-1 expression. J Immunol. 1999; 163:4140-4149. [PubMed: 10510349]

51. Teramachi J, et al. Adenosine abolishes MTX-induced suppression of osteoclastogenesis and inflammatory bone destruction in adjuvant-induced arthritis. Lab Invest. 2011; 91:719-731. [PubMed: 21339747]

52. Rath-Wolfson L, et al. IB-MECA, an A3 adenosine receptor agonist prevents bone resorption in rats with adjuvant induced arthritis. Clin Exp Rheumatol. 2006; 24:400-406. [PubMed: 16956430]

53. Shimegi S. ATP and adenosine act as a mitogen for osteoblast-like cells (MC3T3-E1). Calcif Tissue Int. 1996; 58:109-113. [PubMed: 8998680]

54. Uehara R, et al. Methotrexate (MTX) inhibits osteoblastic differentiation in vitro: possible mechanism of MTX osteopathy. J Rheumatol. 2001; 28:251-256. [PubMed: 11246658]

55. Chan ES, Cronstein BN. Molecular action of methotrexate in inflammatory diseases. Arthritis Res. 2002; 4:266-273. [PubMed: 12106498]

56. Russell JM, et al. Adenosine inhibition of lipopolysaccharide-induced interleukin- 6 secretion by the osteoblastic cell line MG-63. Calcif Tissue Int. 2007; 81:316-326. [PubMed: 17705048]

57. Costa MA, et al. On the role of subtype selective adenosine receptor agonists during proliferation and osteogenic differentiation of human primary bone marrow stromal cells. J Cell Physiol. 2011; 226:1353-1366. [PubMed: 20945394]

58. Jones SJ, et al. Purinergic transmitters inhibit bone formation by cultured osteoblasts. Bone. 1997; 21:393-399. [PubMed: 9356732]

59. Gharibi B, et al. Contrasting effects of $\mathrm{A} 1$ and $\mathrm{A} 2 \mathrm{~b}$ adenosine receptors on adipogenesis. Int $\mathrm{J}$ Obes (Lond). 2012; 36:397-406. [PubMed: 21730968]

60. Gharibi B, et al. Adenosine receptor subtype expression and activation influence the differentiation of mesenchymal stem cells to osteoblasts and adipocytes. J Bone Miner Res. 2011; 26:2112-2124. [PubMed: 21590734]

61. Katebi M, et al. Adenosine A2A receptors play an active role in mouse bone marrow-derived mesenchymal stem cell development. J Leukoc Biol. 2009; 85:438-444. [PubMed: 19056861]

62. Fatokun AA, et al. Hydrogen peroxide-induced oxidative stress in MC3T3-E1 cells: The effects of glutamate and protection by purines. Bone. 2006; 39:542-551. [PubMed: 16616712]

63. Carroll SH, et al. A2B adenosine receptor promotes mesenchymal stem cell differentiation to osteoblasts and bone formation in vivo. J Biol Chem. 2012; 287:15718-15727. [PubMed: 22403399]

64. Takedachi M, et al. CD73-generated adenosine promotes osteoblast differentiation. J Cell Physiol. 2012; 227:2622-2631. [PubMed: 21882189]

65. Ratech $\mathrm{H}$, et al. Pathologic findings in adenosine deaminase-deficient severe combined immunodeficiency. I. Kidney, adrenal, and chondro-osseous tissue alterations. Am J Pathol. 1985; 120:157-169. [PubMed: 4014441]

66. Tesch AM, et al. Effects of an adenosine kinase inhibitor and an adenosine deaminase inhibitor on accumulation of extracellular adenosine by equine articular chondrocytes. Am J Vet Res. 2002; 63:1512-1519. [PubMed: 12428660]

67. Tesch AM, et al. Chondrocytes respond to adenosine via A(2)receptors and activity is potentiated by an adenosine deaminase inhibitor and a phosphodiesterase inhibitor. Osteoarthritis Cartilage. 2002; 10:34-43. [PubMed: 11795981]

68. Petrov R, et al. Inhibition of adenosine kinase attenuates interleukin-1- and lipopolysaccharideinduced alterations in articular cartilage metabolism. Osteoarthritis Cartilage. 2005; 13:250-257. [PubMed: 15727892] 
69. Tesch AM, et al. Endogenously produced adenosine regulates articular cartilage matrix homeostasis: enzymatic depletion of adenosine stimulates matrix degradation. Osteoarthritis Cartilage. 2004; 12:349-359. [PubMed: 15094133]

70. Mistry D, et al. The role of adenosine in chondrocyte death in murine osteoarthritis and in a murine chondrocyte cell line. Osteoarthritis Cartilage. 2006; 14:486-495. [PubMed: 16443378]

71. Bitto A, et al. Polydeoxyribonucleotide reduces cytokine production and the severity of collageninduced arthritis by stimulation of adenosine A((2)A) receptor. Arthritis Rheum. 2011; 63:33643371. [PubMed: 21769841]

72. Varani K, et al. Characterization of adenosine receptors in bovine chondrocytes and fibroblast-like synoviocytes exposed to low frequency low energy pulsed electromagnetic fields. Osteoarthritis Cartilage. 2008; 16:292-304. [PubMed: 17698373]

73. Campo GM, et al. Adenosine A2A receptor activation and hyaluronan fragment inhibition reduce inflammation in mouse articular chondrocytes stimulated with interleukin-1beta. Febs J. 2012; 279:2120-2133. [PubMed: 22502642]

74. Campo GM, et al. The stimulation of adenosine $2 \mathrm{~A}$ receptor reduces inflammatory response in mouse articular chondrocytes treated with hyaluronan oligosaccharides. Matrix Biol. 2012; 31:338-351. [PubMed: 22796382]

75. Campo GM, et al. Protein kinase a mediated anti-inflammatory effects exerted by adenosine treatment in mouse chondrocytes stimulated with IL-1beta. Biofactors. 2012; 38:429-439. [PubMed: 23097357]

76. Burnstock G. Purinergic signalling: Its unpopular beginning, its acceptance and its exciting future. Bioessays. 2012; 34:218-225. [PubMed: 22237698] 


\section{TEXT BOX 1: P2 or nucleotide receptors}

There are two classes of $\mathrm{P} 2$ receptors: ligand-gated ion channels (P2X receptor, ionotropic receptors) or $\mathrm{G}$ protein coupled receptors ( $\mathrm{P} 2 \mathrm{Y}$ receptors, metabotropic receptors) $[2,5,12] . \mathrm{P} 1$ and $\mathrm{P} 2$ receptors have different pharmacological profiles and tissue distribution. Classically, P2X receptors are potently activated by stable ATP analogs such as $a, \beta$-methylene ATP ( $\alpha, \beta$ meATP), and $\beta, \gamma$-meATP, whereas P2Y receptors are activated by 2-methylthio ATP (2MeSATP) [13, 14]. To date, seven mammalian $\mathrm{P} 2 \mathrm{X}$ receptors, $\mathrm{P} 2 \mathrm{X}_{1-7}$, and eight $\mathrm{P} 2 \mathrm{Y}$ receptors $\mathrm{P}_{2} \mathrm{Y}_{1}, \mathrm{P}_{2} \mathrm{Y}_{2}, \mathrm{P}_{2} \mathrm{Y}_{4}, \mathrm{P}_{2} \mathrm{Y}_{6}$, $\mathrm{P}_{2} \mathrm{Y}_{11}, \mathrm{P}_{2} \mathrm{Y}_{12}, \mathrm{P}_{2} \mathrm{Y}_{13}$ and $\mathrm{P} 2 \mathrm{Y}_{14}$ have been cloned, characterized pharmacologically and accepted as valid members of the $\mathrm{P} 2$ receptor family[15](Table 2). P2X receptors are ATP-gated ion channels which mediate rapid (within $10 \mathrm{~ms}$ ) and selective permeability to cations such as $\mathrm{Na}^{+}, \mathrm{K}^{+}$and $\mathrm{Ca}^{2+}[16]$.

$\mathrm{P} 2 \mathrm{Y}$ receptors are expressed on the surface of all cell types. Nevertheless, $\mathrm{P} 2 \mathrm{Y}_{11}, \mathrm{P}_{2} \mathrm{Y}_{12}$, $\mathrm{P}_{2} \mathrm{Y}_{13}$ and $\mathrm{P}_{2} \mathrm{Y}_{14}$ receptors are known for their specific role in the stimulation of platelet aggregation and vascular tone [17]. P2Y receptors are primarily coupled by Gq to phospholipase C (PLC) with subsequent formation of inositol triphosphate (IP3) and diacylglycerol (DAG). $\mathrm{P} 2 \mathrm{Y}_{13}$ and $\mathrm{P} 2 \mathrm{Y}_{14}$ are also negatively coupled to adenylate cyclase through $\mathrm{Gi}$, and $\mathrm{P} 2 \mathrm{Y}_{1}$ and $\mathrm{P} 2 \mathrm{Y}_{2}$ are also coupled to the RhoA / ROCK-I and ERK1/2 pathways [18].

\section{TEXT BOX 1 TABLE I}

P2 or Nucleotide receptors:

\begin{tabular}{|c|c|c|c|c|c|}
\hline \multicolumn{2}{|c|}{ Receptor } & \multirow{2}{*}{$\begin{array}{l}\begin{array}{l}\text { Agonist } \\
\text { (Rank potency) }\end{array} \\
\text { Bz-ATP > } \\
2-M e S A T P ~ \geq \\
\text { ATP }> \\
\text { a }, \beta-M e A T P ~>> \\
\text { ADP }\end{array}$} & \multirow{2}{*}{$\begin{array}{l}\begin{array}{l}\text { Antagonist } \\
\text { (rank potency) }\end{array} \\
\text { NF449 > IP5I > } \\
\text { TNP-ATP> } \\
\text { RO 0437626> } \\
\text { NF279, NF023, } \\
\text { RO1, MRS2159 }\end{array}$} & \multirow{2}{*}{$\begin{array}{l}\begin{array}{l}\text { Transduction } \\
\text { mechanism }\end{array} \\
\text { Intrinsic } \\
\text { cation channel } \\
\left(\mathrm{Ca}^{2+} \text { and } \mathrm{Na}^{+}\right)\end{array}$} & \multirow{2}{*}{$\begin{array}{l}\text { REF } \\
{[2,} \\
5, \\
12-14, \\
16, \\
17]\end{array}$} \\
\hline P2X & $\mathrm{P} 2 \mathrm{X}_{1}$ & & & & \\
\hline & $\mathrm{P} 2 \mathrm{X}_{2}$ & $\begin{array}{l}\text { ATP } \geq \\
\text { ATP } \gamma S \geq \\
2 \text {-MeSATP >> } \\
\text { a, } \beta \text {-meATP }\end{array}$ & $\begin{array}{l}\text { PSB-1011 > } \\
\text { RB2, } \\
\text { isoPPADS } \\
\text { >PPADS > } \\
\text { Suramin, } \\
\text { NF770, NF778, } \\
\text { aminoglycoside }\end{array}$ & $\begin{array}{l}\text { Intrinsic } \\
\text { ion channel } \\
(\text { particularly } \\
\left.\mathrm{Ca}^{2+}\right)\end{array}$ & $\begin{array}{l}{[2,5,} \\
12-14, \\
16, \\
17]\end{array}$ \\
\hline & $\mathrm{P} 2 \mathrm{X}_{3}$ & $\begin{array}{l}\text { Bz-ATP }>> \\
\text { 2-MeSATP }> \\
\text { ATP }=a, \beta-M e A T P\end{array}$ & $\begin{array}{l}\text { TNP-ATP, } \\
\text { isoPPADS > } \\
\text { A317491 > } \\
\text { NF110 > } \\
\text { PPADS, Ip5I, } \\
\text { phenol red, } \\
\text { RO4, RN-1838, } \\
\text { Spinorphin, } \\
\text { AF353 }\end{array}$ & $\begin{array}{l}\text { Intrinsic } \\
\text { cation channel }\end{array}$ & $\begin{array}{l}{[2,} \\
5, \\
12-14, \\
16, \\
17, \\
76]\end{array}$ \\
\hline & $\mathrm{P} 2 \mathrm{X}_{4}$ & $\begin{array}{l}\text { UDP }=5 \mathrm{Br}-\mathrm{UDP}>> \\
\mathrm{UTP}>2-\mathrm{MeSADPBz}-\mathrm{ATP}= \\
\text { ATP }\end{array}$ & $\begin{array}{l}\text { 5-BDBD } \\
\text { TNP-ATP, } \\
\text { PPADS>BBG, } \\
\text { Paroxetine, } \\
\text { phenolphthalein, }\end{array}$ & $\begin{array}{l}\text { Intrinsic } \\
\text { ion channel } \\
\text { (especially } \\
\mathrm{Ca}^{2+} \text { ) }\end{array}$ & $\begin{array}{l}{[2,} \\
5, \\
12-14, \\
16, \\
17, \\
76]\end{array}$ \\
\hline & $\mathrm{P} 2 \mathrm{X}_{5}$ & $\begin{array}{l}\text { ATP >> } \\
\text { a, } \beta \text {-meATP> } \\
\text { ADP }\end{array}$ & $\begin{array}{l}\text { BBG > PPADS, } \\
\text { Suramin }\end{array}$ & $\begin{array}{l}\text { Intrinsic } \\
\text { ion channel }\end{array}$ & $\begin{array}{l}{[2,} \\
5, \\
12-14, \\
16, \\
17, \\
76]\end{array}$ \\
\hline
\end{tabular}




\begin{tabular}{|c|c|c|c|c|c|}
\hline \multicolumn{2}{|c|}{ Receptor } & \multirow{2}{*}{$\begin{array}{l}\begin{array}{l}\text { Agonist } \\
\text { (Rank potency) }\end{array} \\
\text { ATP > } \\
\text { 2-MeSATP > } \\
\text { ADP }\end{array}$} & \multirow{2}{*}{$\begin{array}{l}\text { Antagonist } \\
\text { (rank potency) }\end{array}$} & \multirow{2}{*}{$\begin{array}{l}\begin{array}{l}\text { Transduction } \\
\text { mechanism }\end{array} \\
\text { Intrinsic } \\
\text { ion channel }\end{array}$} & \multirow{2}{*}{$\begin{array}{l}\text { REF } \\
{[2,} \\
5, \\
12-14 \\
16, \\
17] \\
{[76]}\end{array}$} \\
\hline & $\mathrm{P} 2 \mathrm{X}_{6}$ & & & & \\
\hline & $\mathrm{P} 2 \mathrm{X}_{7}$ & $\begin{array}{l}\text { Bz-ATP > } \\
\text { ATP > } \\
\text { 2-MeSATP >> } \\
\text { a, } \beta \text {-meATP }\end{array}$ & $\begin{array}{l}\text { KN62, BBG, } \\
\text { KN04, } \\
\text { MRS2427, O- } \\
\text { ATP, RN-6189, } \\
\text { AZ10606120, } \\
\text { A740003, } \\
\text { A-438079, } \\
\text { A-804598, } \\
\text { GSK-1370319, } \\
\text { Compound 31 } \\
\text { (GSK), } \\
\text { AZD-9056, } \\
\text { CE-224535 }\end{array}$ & $\begin{array}{l}\text { Intrinsic } \\
\text { cation channel } \\
\text { and a large pore } \\
\text { with prolonged } \\
\text { activation }\end{array}$ & $\begin{array}{l}{[2,} \\
5, \\
12-14, \\
16, \\
17, \\
76]\end{array}$ \\
\hline \multirow[t]{5}{*}{ P2Y } & $\mathrm{P}_{2} \mathrm{Y}_{1}$ & $\begin{array}{l}\text { (N)-mc-2-MeSADP> } \\
\text { 2-MeSADP }> \\
\text { ADP=ADPBS >> } \\
\text { ATP2-MeSATP> } \\
\text { ADP }> \\
\text { ATP2-MeSADP=2-MeSATP> } \\
\text { ADP2-MeSATP> } \\
\text { 2Cl-ATP }> \\
\text { ATP }\end{array}$ & $\begin{array}{l}\text { MRS2500 > } \\
\text { MRS2279 > } \\
\text { MRS2179, PIT, } \\
\text { A3P5P }\end{array}$ & $\begin{array}{l}\mathrm{G}_{\mathrm{q}} / \mathrm{G}_{11} \text { PLC } \beta \\
\text { activation }\end{array}$ & $\begin{array}{l}{[2,} \\
5, \\
12-14, \\
17, \\
18, \\
76]\end{array}$ \\
\hline & $\mathrm{P} 2 \mathrm{Y}_{2}$ & $\begin{array}{l}\text { UTP }=\text { ATP> } \\
\text { INS37217> } \\
\text { Ap4A> } \\
\text { ATP } \gamma \\
\text { S }> \\
\text { UTP } \geq \\
\text { ATP> } \\
\text { ADP> 2-MeSATP } \\
\text { UTP> } \\
\text { ITP> } \\
\text { ATP }>\text { UDP } \\
\text { UTP=ATP> } \\
\text { CTP> } \\
\text { GTP } \\
\text { UTP }=\text { ATP }> \\
\text { Ap } 4\end{array}$ & $\begin{array}{l}\text { AR-C126313> } \\
\text { Suramin> } \\
\text { RB2, PSB-716, } \\
\text { MRS2576 }\end{array}$ & $\begin{array}{l}\mathrm{G}_{\mathrm{q}} / \mathrm{G}_{11} \text { and } \\
\text { possibly } \mathrm{G}_{\mathrm{i}} \\
\text { PLC } \beta \\
\text { activation }\end{array}$ & $\begin{array}{l}{[2,} \\
5, \\
12-15, \\
17, \\
76]\end{array}$ \\
\hline & $\mathrm{P}_{2} \mathrm{Y}_{4}$ & $\begin{array}{l}\mathrm{UTP}>\mathrm{UTP} \gamma \mathrm{S} \\
\mathrm{UTP}=\mathrm{ATP}=\mathrm{ITP}=\mathrm{Ap}_{4} \mathrm{~A} \\
\mathrm{UTP}=\mathrm{ATP}\end{array}$ & $\begin{array}{l}\text { ATP (human) > } \\
\text { Reactive Blue } 2 \\
>\text { Suramin, } \\
\text { MRS2577, } \\
\text { PPADS }\end{array}$ & $\begin{array}{l}\mathrm{G}_{\mathrm{q}} / \mathrm{G}_{11} \text { and } \\
\text { possibly } \\
\mathrm{G}_{\mathrm{i}} \mathrm{PLC} \beta \\
\text { activation }\end{array}$ & $\begin{array}{l}{[2,} \\
5, \\
12-14, \\
17, \\
76]\end{array}$ \\
\hline & $\mathrm{P}_{2} \mathrm{Y}_{6}$ & $\begin{array}{l}\text { UDP }=5 \text { Br-UDP }> \\
\text { UTP> } \\
2 \text {-MeSADP } \\
\text { UDP> } \\
\text { UTP> } \\
\text { ADP> } \\
\text { 2-MeSATP } \\
\text { UDP> } \\
\text { UTP> } \\
\text { ADP> } \\
\text { 2-MeSATP }\end{array}$ & $\begin{array}{l}\text { MRS2578 > } \\
\text { Reactive Blue 2, } \\
\text { PPADS, } \\
\text { MRS2567, } \\
\text { MRS2575 } \\
\text { (human) }\end{array}$ & $\begin{array}{l}\mathrm{G}_{\mathrm{q}} / \mathrm{G}_{11} \text { PLC } \beta \\
\text { activation }\end{array}$ & $\begin{array}{l}{[2,} \\
5, \\
12-14, \\
17, \\
76]\end{array}$ \\
\hline & $\mathrm{P} 2 \mathrm{Y}_{11}$ & 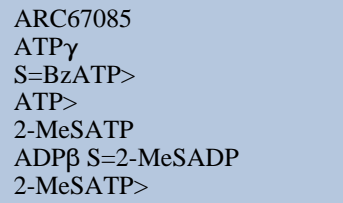 & $\begin{array}{l}\text { NF157 > } \\
\text { Suramin > }\end{array}$ & $\begin{array}{l}\mathrm{G}_{\mathrm{q}} / \mathrm{G}_{11} \text { and } \mathrm{G}_{\mathrm{s}} \\
\mathrm{PLC} \beta \text { activation }\end{array}$ & $\begin{array}{l}{[2,} \\
5, \\
12-14, \\
17,\end{array}$ \\
\hline
\end{tabular}




\begin{tabular}{|c|c|c|c|c|}
\hline \multirow[t]{2}{*}{ Receptor } & $\begin{array}{l}\text { Agonist } \\
\text { (Rank potency) }\end{array}$ & $\begin{array}{l}\text { Antagonist } \\
\text { (rank potency) }\end{array}$ & $\begin{array}{l}\text { Transduction } \\
\text { mechanism }\end{array}$ & REF \\
\hline & ATP & $\begin{array}{l}\text { RB2, 50-AMPS, } \\
\text { NF340, AMP- } \\
\text { a-5, }\end{array}$ & & $76]$ \\
\hline $\mathrm{P} 2 \mathrm{Y}_{12}$ & $\begin{array}{l}\text { 2-MeSADP> } \\
\text { ADP > } \\
\text { (N)-mc-2-MeSADP } \\
\text { 2-MeSADP > } \\
\text { ADP, ATP } \\
\text { 2-MeSADP> } \\
\text { ADP> } \\
\text { ATP } \\
\text { 2-MeSADP> } \\
\text { ADP> } \\
\text { ADP } 3\end{array}$ & $\begin{array}{l}\text { AR- } \\
\text { C69931MX> } \\
\text { AZD6140, } \\
\text { INS50589> } \\
\text { RB2 > } \\
\text { 2-MeSAMP, } \\
\text { AR-C66096, } \\
\text { CT50547, } \\
\text { PSB-0413, } \\
\text { Carba- } \\
\text { nucleosides, } \\
\text { MRS2395, AR- } \\
\text { C67085 }\end{array}$ & $\begin{array}{l}\mathrm{G}_{\mathrm{i}} \text { inhibition of } \\
\text { adenylate } \\
\text { cyclase }\end{array}$ & $\begin{array}{l}{[2,} \\
5, \\
12-14, \\
17, \\
76]\end{array}$ \\
\hline $\mathrm{P} 2 \mathrm{Y}_{13}$ & $\begin{array}{l}2-\mathrm{MeSADP} \geq \\
\text { ADP }> \\
\text { ADP } \beta \text { S } \\
\text { ADP }>2-\mathrm{MeSADP}>> \\
\text { ATP } \\
\text { ADP=2-MeSaDP=ADP } \beta \\
\text { S }> \\
\text { ATP }\end{array}$ & $\begin{array}{l}\text { AR-C69931MX } \\
> \\
\text { AR-C67085 > } \\
\text { MRS2211, 2- } \\
\text { MeSAMP }\end{array}$ & $\mathrm{G}_{\mathrm{i}}$ & $\begin{array}{l}{[2,} \\
5, \\
12-14, \\
17, \\
76]\end{array}$ \\
\hline $\mathrm{P} 2 \mathrm{Y}_{14}$ & $\begin{array}{l}\text { UDP-glucosa> } \\
\text { UDP-galactosa }\end{array}$ & & $\mathrm{G}_{\mathrm{i} / \mathrm{o}}$ & $\begin{array}{l}{[2,} \\
5, \\
12-14, \\
17, \\
76]\end{array}$ \\
\hline
\end{tabular}




\section{Outstanding questions}

- What intracellular pathways are activated by adenosine and its receptors to promote or inhibit osteoclast/osteoblast differentiation?

- Is there a translational role for targeting adenosine receptors in the therapy of bone resorption, arthritis and fracture healing? 


\section{Highlights}

- Adenosine and its receptors are critical regulators of osteoclast differentiation.

- Adenosine $A_{2 B}$ receptor is critical for osteoblast differentiation but the other three adenosine receptors also play a major role in bone formation.

- Adenosine $\mathrm{A}_{2 \mathrm{~A}}$ receptor may be an important regulator of cartilage loss. 


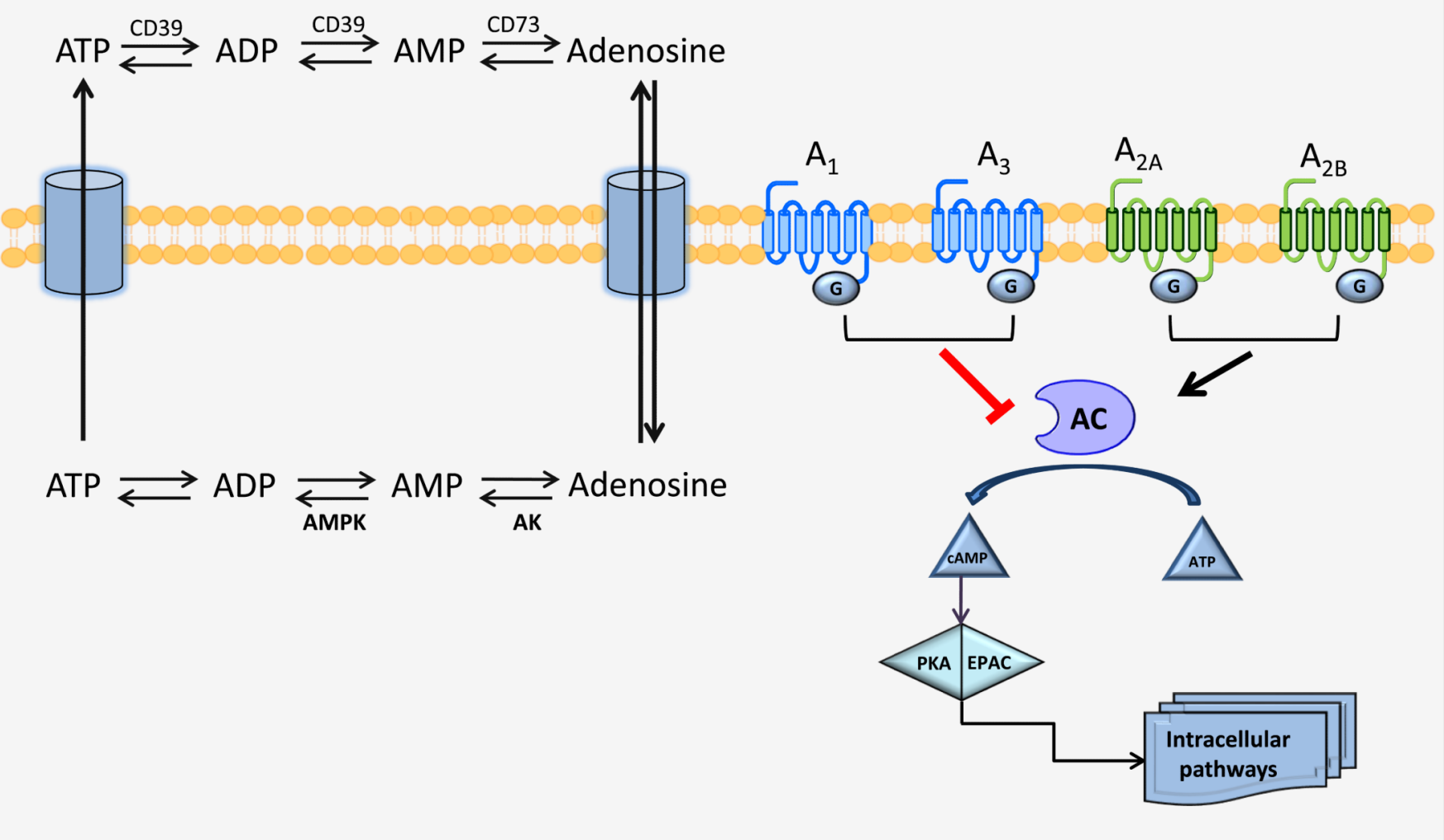

Figure 1. Adenosine synthesis and receptor activation in the cell Under physiological conditions, ATP is converted to adenosine via a series of dephosphorylation steps involving cytosolic ecto 5'-nucleotidases CD39 and CD73. Adenosine is converted to ATP via phosphorylation steps mediated by adenosine kinase (AK), and AMP kinase (AMPK). Both ATP and adenosine can be transported outside the cell via diffusion or active transport. Outside the cell, there is again ATP metabolic degradation to adenosine, which activates one of the four adenosine receptors $\left(A_{1} R, A_{2 A} R\right.$, $A_{2 B} R$ and $\left.A_{3} R\right)$. Once the receptors are activated, there is a positive $\left(A_{2 A} R, A_{2 B} R\right)$ or negative $\left(A_{1} R\right.$ and $\left.A_{3} R\right)$ coupling to $A C$ with the corresponding activation of inhibition of cAMP, that will differentially activates PKA, EPAC and several intracellular pathways. 


\section{Osteoclast precursor}

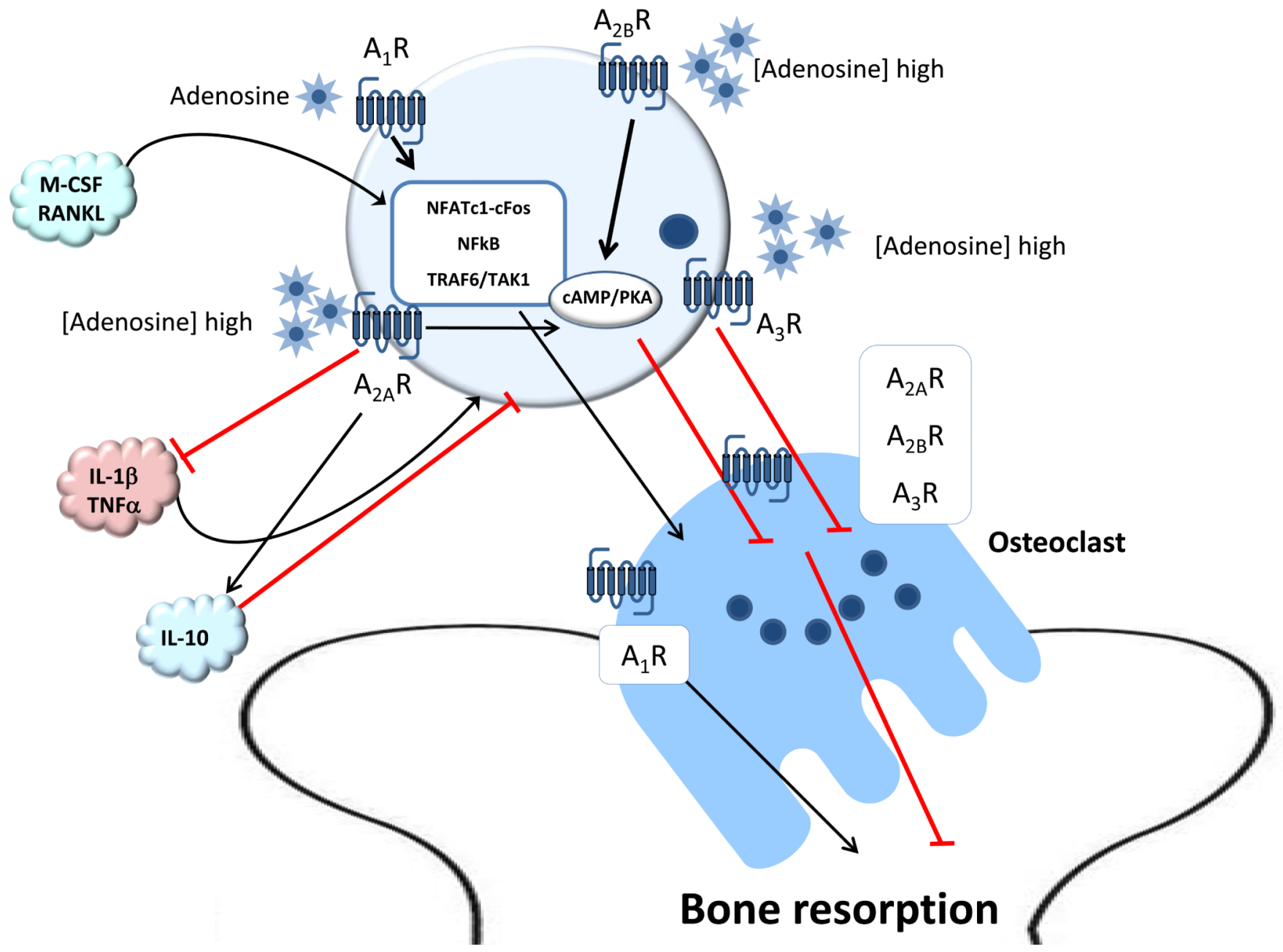

Figure 2. Role of adenosine and its receptors in osteoclast metabolism

Under physiological conditions, intracellular adenosine concentrations are relatively low. $\mathrm{A}_{1} \mathrm{R}$ is activated in osteoclast precursors and this produces osteoclast differentiation by RANKL-induced expression of the transcription factors NFATc1 and c-fos, induction of NFאB nuclear translocation and formation of the TRAF6-TAK1 complex. When adenosine levels increased due to inflammation for example, the other adenosine receptors are activated. Once $\mathrm{A}_{2 \mathrm{~A}} \mathrm{R}$ is activated, MCSF and RANKL secretion is inhibited, proinflammatory cytokine (IL-1 $\beta$ and TNFa) secretion is decreased while IL-10 expression is increased, leading to osteoclast differentiation inhibition. Little is known about how $\mathrm{A}_{2 \mathrm{~B}} \mathrm{R}$ and $\mathrm{A}_{3} \mathrm{R}$ exerts inhibition of osteoclast differentiation. 


\section{Mesenchymal precursor}

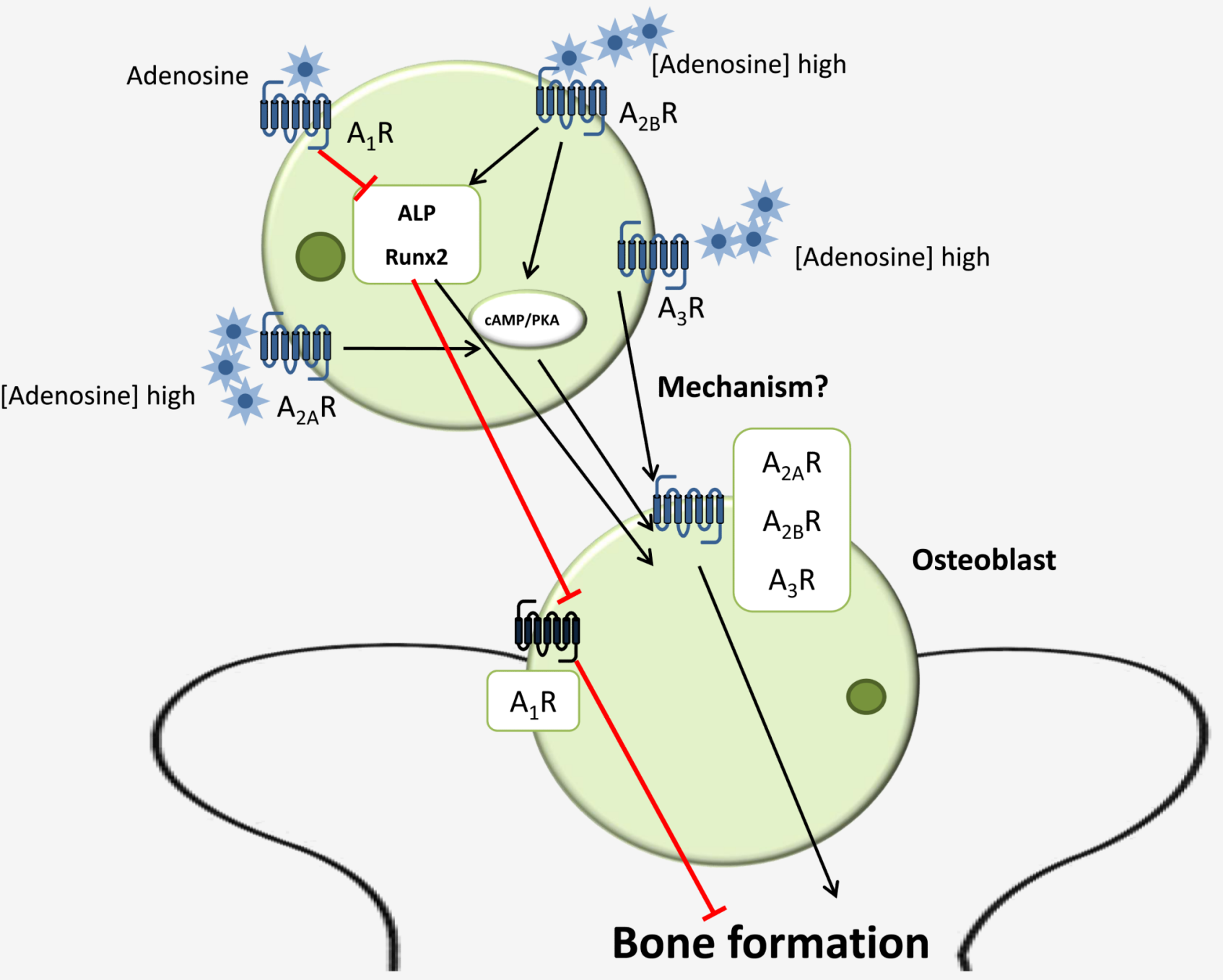

Figure 3. Role of adenosine and its receptors in osteoblast metabolism

$\mathrm{A}_{1} \mathrm{R}$ is present in mesenchemical stems cells and it's activation produce the inhibition os osteoblast differentiation reflected in the decreased of ALP activity observed, with. $\mathrm{A}_{2 \mathrm{~A}} \mathrm{R}$, is induced due to inflammation (IL-6), and in a cAMP/PKA-dependent mechanism it activates osteoblast differentiation. When $\mathrm{A}_{2 \mathrm{~B}} \mathrm{R}$ is activated, osteoblast differentiation and bone formation are increased by activating the expression of osteoblast-related genes Runx 2 and ALP. $A_{3} R$ is present in both osteoblast and osteoblast precursors and its activation increases osteoblasts proliferation but little is known about the mechanisms involved. 


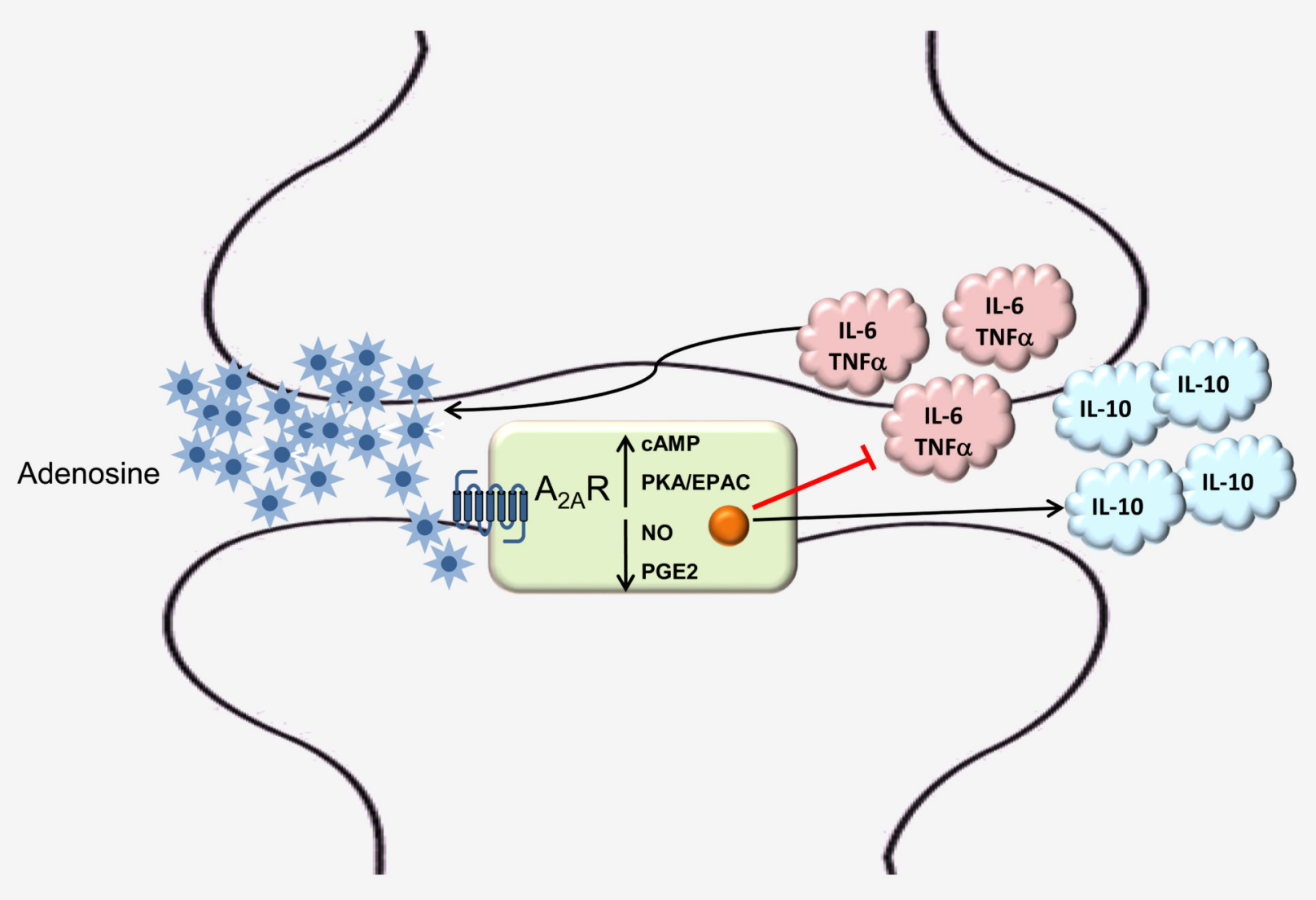

Figure 4. Role of adenosine $A_{2 A} R$ in cartilage metabolism

When inflammation is produced in the articular cartilage (IL-6 and TNFa), adenosine is secreted and $\mathrm{A}_{2 \mathrm{~A}} \mathrm{R}$ is activated in chondrocytes, producing an increase in intracellular cAMP levels, together with a suppression of NO, and PGE2 release, and enhanced IL-10 expression. This, in combination with activation of PKA and EPAC produce a decrease on inflammation and ameliorate the progression of illness and cartilage degeneration. 
TABLE 1

P1 or Adenosine receptors:

\begin{tabular}{|c|c|c|c|c|}
\hline Receptor & Agonist & Antagonist & Transduction mechanism & REF \\
\hline $\mathbf{A}_{1}$ & $\begin{array}{l}\text { Adenosine } \\
\text { N6-Cyclopentyladenosine } \\
\text { (CPA)CCPA } \\
\text { 2'-MeCCPA } \\
\text { GR79236 } \\
\text { S-ENVA } \\
\text { CVT510 }\end{array}$ & $\begin{array}{l}\text { Caffeine } \\
\text { Theophylline } \\
\text { 8-Cyclopentyl-1,3 dimethylxanthine (CPX) } \\
\text { 8-Cyclopentyl-1,3-dipropylxanthine } \\
\text { (DPCPX) } \\
\text { 8-Phenyl-1,3-dipropylxanthine } \\
\text { PSB36 } \\
\text { N-0840 } \\
\text { MRS1754 } \\
\text { WRC-0571 }\end{array}$ & $\mathrm{G}_{\mathrm{i} / \mathrm{d}}$ diminish cAMP & {$[3-8]$} \\
\hline $\mathbf{A}_{2 \mathrm{~A}}$ & $\begin{array}{l}\text { Adenosine } \\
\text { ATL146e } \\
\text { CGS21680 } \\
\text { Regadenoson } \\
\text { HE-NECA } \\
\text { CVT3146 }\end{array}$ & $\begin{array}{l}\text { Caffeine } \\
\text { Theophylline } \\
\text { Istradefylline } \\
\text { SCH58261 } \\
\text { SCH442416 } \\
\text { ZM241385 } \\
\text { KF17837 } \\
\text { KW6002 }\end{array}$ & $\mathrm{G}_{\mathrm{S}}$ increase $\mathrm{cAMP}$ & [3-8] \\
\hline $\mathbf{A}_{2 \mathrm{~B}}$ & $\begin{array}{l}\text { Adenosine } \\
5^{\prime} \text {-N-ethylcarboxamidoadenosine } \\
\text { BAY606583 } \\
\text { LUF5835 } \\
\text { LUF5845 } \\
\text { NECA (non selective) }\end{array}$ & $\begin{array}{l}\text { Caffeine } \\
\text { Theophylline } \\
\text { CVT6883 } \\
\text { MRS1706 } \\
\text { MRS17541 } \\
\text { PSB603 } \\
\text { PSB0788 } \\
\text { PSB1115 } \\
\text { Enprofylline } \\
\text { MRE2029 }\end{array}$ & $\mathrm{G}_{\mathrm{S}}$ increase $\mathrm{cAMP}$ & {$[3-8]$} \\
\hline $\mathbf{A}_{3}$ & $\begin{array}{l}\text { Adenosine } \\
\text { 2-(1-Hexynyl)-N-methyladenosine } \\
\text { CF101 (IB-MECA) } \\
\text { 2-Cl-IB-MECA } \\
\text { CP532903 } \\
\text { MRS3558 } \\
\text { DBXRM } \\
\text { VT160 }\end{array}$ & $\begin{array}{l}\text { Caffeine } \\
\text { Theophylline } \\
\text { MRS1191 } \\
\text { MRS1220 } \\
\text { MRS1334 } \\
\text { MRS1523 } \\
\text { MRS3777 } \\
\text { MRE3008F20 } \\
\text { PSB10 } \\
\text { PSB11 } \\
\text { VUF5574 } \\
\text { L268605 }\end{array}$ & $\begin{array}{l}\mathrm{G}_{\mathrm{i} / \mathrm{o}} \mathrm{G}_{\mathrm{q} / 11} \text { decrease cAMP and } \\
\text { increase } \mathrm{IP}_{3}\end{array}$ & [3-8] \\
\hline
\end{tabular}

